Original research article

\title{
Participants' experiences of rehabilitation camp
}

\author{
Zuzana Rodová ${ }^{1,2}$ *, Petra Sládková ${ }^{1}$, Anna Kuželková ${ }^{1,3}$ \\ ${ }^{1}$ Charles University, First Faculty of Medicine and General University Hospital in Prague, Department of Rehabilitation Medicine, Prague, \\ Czech Republic \\ ${ }^{2}$ Charles University, First Faculty of Medicine, Department of Addictology, Prague, Czech Republic \\ ${ }^{3}$ University of South Bohemia in České Budějovice, Faculty of Health and Social Sciences, České Budějovice, Czech Republic
}

\begin{abstract}
Background: Enabling people to return to independent living following Acquired Brain Injury (ABI) is a challenge for rehabilitation. In co-operation with the Department of Rehabilitation Medicine, Prague, Czech Republic, the non-governmental organization Rehalb holds week-long rehabilitation camps $(\mathrm{RC})$. These deliberately take people from the hospital setting to a more demanding environment in order to encourage attendees to become more independent.

Aim: This study aimed to uncover and describe the personal experiences of rehabilitation camp participants.

Methods: A phenomenological approach was used. Data were gathered from 6 in-depth interviews.

Results: The RCs seem to provoke enhanced opportunities within the participants' changed capacities. The camp's activities provided opportunities for easier re-integration into society; significant progress was being observed in related aspects. Six themes, which incorporated several categories, were identified: "Doing more"; "Escaping stereotypes"; "Discovering hidden potential"; "Finding independence"; "Transferring to normal life" and "Building relationships".

Conclusions: The natural and constantly stimulating rehabilitation environment of the camps can be considered a very appropriate setting for interdisciplinary stimulation of independence skills of the ABI clients. In that matter, the RCs could be considered an important component of the rehabilitation process for people with the ABI diagnosis.
\end{abstract}

Keywords: Acquired brain injury; Adult; Interdisciplinary team; Occupational therapy; Rehabilitation camp

\section{Introduction}

Acquired brain injury and mainly stroke are very common worldwide and have a severe effect on human life. Coordinated rehabilitation is needed to reach maximal self-independence and quality of life (Vacková et al., 2020). According to the WHO (2017), "rehabilitation is a set of interventions designed to optimize functioning and reduce disability in individuals with health conditions in interaction with their environment".

One of the greatest challenges within rehabilitation services is the provision of opportunities for people to realise and develop a meaningful life in the context of their changed capacities in everyday activities. Hospital settings provide vital care during times of crisis, but it is now being realised that dependence can be too quickly established in such environments. Increased attention is now being paid worldwide to the importance of enabling people to practice daily tasks again within ordinary life settings; a principle that has always underpinned occupational therapy (Vacková et al., 2020). This research is focused on the experience of one aspect of the rehabilitation following $\mathrm{ABI}$, namely attendance at a camp located in the natural environment, away from family and hospital settings. Accompanied by rehabilitation professionals who volunteer to spend time with the residents to facilitate engagement in a variety of activities, people seem to gain a lot from these experiences; although how and what requires further scientific analyses (Rodová and Nováková, 2011).

The rehabilitation of individuals following $\mathrm{ABI}$ requires an interdisciplinary team, consisting of both medical and social services, to act in a coordinated manner to ensure successful reintegration of the clients into everyday life (Švestková et al., 2017). The agreed therapeutic approach should guarantee both efficiency in relation to the clients as well as reflect the economic aspects of the care provided.

Nowadays in the Czech Republic, although most of the individual components of the rehabilitation process are of very good quality, the lack of systematic coordination hampers efficacious treatment (Maršálek et al., 2011). As a result, the clients often have to search for a suitable rehabilitation care setting by themselves, or with the help of their families. This is coherent to Vacková et al. (2020) who states that coordinated rehabilitation needs good cooperation of the interdisciplinary team. That is often not achieved.

\footnotetext{
* Corresponding author: Zuzana Rodová, Charles University, First Faculty of Medicine and General University Hospital in Prague, Department of Rehabilitation Medicine, Albertov 7, 12800 Prague 2, Czech Republic; e-mail: zuzana.rodova@lf1.cuni.cz http://doi.org/10.32725/kont.2021.034

Submitted: 2020-12-15 • Accepted: 2021-07-12 • Prepublished online: 2021-08-03 
To address this problem, in cooperation with the Department of Rehabilitation Medicine of 1st Faculty of Medicine, Charles University and University Hospital in Prague, the non-governmental organization (NGO) "Rehalb" organizes a special one-week programme for ABI clients, the so-called "Rekondiční pobyt" (Vacková et al., 2020). The term is rather difficult to translate into English; the term "re-condition" includes the idea of re-initiation, i.e. to repair, or to restore and return to the normal state. Thus, the closest meaning in the English language seems to be in the sense of a "rehabilitation camp" (RC). The camps started in 2003 and each year two of them are held. From 2010, shorter weekend stays were also established.

Over the years, the programme has evolved from an initial concept of "Treatment in nature" to more of an emphasis on the performance of normal life-like activities and occupations in the natural environment. Wilcock and Hocking (2015) define occupation as follows: "All that people need, want, or are obliged to do; what it means to them." Therefore, the idea behind these RCs is to take attendees out of the hospital settings to a resort situated in the natural environment in South Bohemia. There, in the absence of their families, they can develop independence skills in Activities of Daily Living (ADL) (Goodwin and Staples, 2005; O'Mahar et al., 2010). As well as this, the clients can also enhance their occupational potential.

The activities carried out at the camp do not only simulate ordinary duties, such as self-care (Rodová and Nováková, 2011). They also comprise entertaining events, including trips to the city, visits to coffee bars, dancing, watching movies, and sports such as fishing or golf (O'Mahar et al., 2010). All activities are performed in a group environment'. The RC lasts one week, and is paid for by the participant and co-funded by a sponsor.

Next, an interdisciplinary team of eight members guarantees comprehensive supervision of the RC - an Occupational Therapist (OT), a Physiotherapist (PT), a Medical Doctor (MD), a manager and four undergraduate students (two OT and two PT students). "One $R C$ is designed for 16 participants with a different combination of difficulties: physical, sensitive, speech, cognitive and difficulties with self-care." (Rodová and Nováková, 2011)

Individuals are enrolled from the daycare centre or are outpatient clients of the Department of Rehabilitation Medicine. The entry criteria reflect whether they are suitable to undergo group therapy, and their interest, willingness to co-operate and motivation. Overall, the clients are chosen by MDs and therapists.

Due to a systemic inconsistency in the Czech Republic in providing health and social care for clients with ABI diagnosis, the RCs are, in a way, "bridging" these two disciplines (Rodová and Nováková, 2011). Following the initial discharge from the hospital setting, the camps can facilitate an easier reintegration into society for the clients. Having participated in the camp, some clients display a reduced need for assistance or require less outpatient treatment. In the camps, the clients are encouraged to take care of themselves as much as possible, receiving help only on request. In this way, the clients are motivated to realize the extent of the activities feasible. This is a very important aspect of the philosophy of the camps.

In recent years health-related camping programmes have proliferated and now have a tradition - especially in the United States (Goodwin and Staples, 2005; Kiernan et al., 2004; O'Mahar et al., 2010). Nowadays, in the US and Europe there is a big variety in camping programmes according to the target group; age (children, young adults, adults, seniors); diagnosis
(Stroke, Spina Bifida, Spinal Cord Injury, chronic disease, oncology, Multiple Sclerosis, ABI, etc.); the programme offered (individual or group treatment) and others (Kejklícková, 2011; Kiernan et al., 2004). In the Czech Republic, a spectrum of patient organizations and health or non-health organizations frequently offer various types of organized activity. In particular, the following associations focus on clients with ABI diagnosis: Ictus, Cerebrum, and Stroke association. Unfortunately, there is no relevant scientific article available from the $\mathrm{Czech}$ environment. All the Czech literature found was mainly webbased information for clients and family members, derived from the years of experiences of different camp organizers. We can see in practice how psychological well-being significantly affects the outcome of the treatment, which is one of the aspects of the RC. It is possible to observe changes in the participants after a week of RC, both mental and physical. Kejklíčková (2011) states: "In the group, it is very nice to develop feelings of belonging and belief in improvement." During RC the participants deal with the various matters of everyday life and the RC helps them to master skills in the following areas: social (independence, contacts, family), psychological, health (fitness, climate), and occupational (habits, cooking, cleaning).

\section{Materials and methods}

The literature survey indicates that, as of yet, this particular issue has neither been described in general nor in more detail. On the contrary, there is a large knowledge gap in the field of $\mathrm{RC}$-related literature. The proposed study is unique in that it arises from a background where RCs have a strong tradition. Moreover, it directly surveys the individual experience of camp participants. Thus, both factors are likely to provide a robust contribution to the elucidation of the putative effects of camp participation.

\section{Study design}

The research question that evolved from the literature review was: "How do participants experience their activities at an occupational-based rehabilitation camp?" The goals of this research are to study the experience, perceived influence, and meaning or felt effects of the RCs as seen from the perspective of the participants. Thus a qualitative research design with a phenomenological approach was appropriate. According to DePoy and Gitlin (2019), phenomenology interprets the meanings of experience; a phenomenologist believes that the meaning and relevance of human action can be best understood only by those who experience it.

The method was to undertake profound, in-depth interviews with people who have previously taken part in the RCs. In the findings, quotes from attendees support and validate the statement about benefits and the importance of RCs (Kilhofner, 2006).

\section{Sample}

Using a purposive sampling strategy described by Kilhofner (2006), the study participants were enrolled from a list of RC attendees. The inclusion criterion was as follows: attendees of the RCs organized by Rehalb. Exclusion criteria were: having communication problems (aphasia) and memory-related problems. The participants were sorted according to those criteria. Suitable persons were contacted by phone or personally. The study included the first six participants, who had agreed to participate (shown in the Table 1). 
Table 1. Basic information about the participants

\begin{tabular}{|c|c|c|c|c|c|}
\hline Participant & Gender & Mobility & Necessary assistance during ADL & $\begin{array}{l}\text { No. of Camp } \\
\text { attendance }\end{array}$ & $\begin{array}{c}\text { Home situation } \\
\text { (living with) }\end{array}$ \\
\hline A. & female & wheelchair & some activity from iADL & $4 x+$ weekends & husband and son \\
\hline B. & male & wheelchair & some activity from iADL & $1 x$ & mother \\
\hline C. & female & walking & only a few activities from iADL & $1 \times$ & boyfriend \\
\hline D. & male & walking & some $\mathrm{pADL}$, some $\mathrm{iADL}$ & $2 x$ & wife \\
\hline E. & female & walking & only a few activities from iADL & $2 x+$ weekends & mother \\
\hline F. & female & wheelchair & some $\mathrm{pADL}$, some iADL & $4 \times+$ weekends & parents \\
\hline
\end{tabular}

Two participants attended the camp for the first time; two had two previous experiences with camps, and two had four. Such distribution brings a diversified perspective to the research. Experienced participants answered additional questions concerning the long-term camp benefits, progress potential, and in addition, transfer of the skills gained to their normal life. For the protection of confidentiality and identity, further personal information is omitted from the table. The age of the participants ranged from 23 to 70 years, with a median of 44 years. The diagnosis of all participants was ABI; two participants after stroke, two TBI, and two following neoplastic brain disease.

\section{Method of data gathering}

In-depth interviews were carried out with six participants following their attendance of a RC. The interviews were led according to a prepared interview guide, with the main intention to survey their experience (Hendl, 2016). A maximum length of 60 minutes was established for the interviews; the actual length reflected the amount of information being acquired (Hendl, 2016). The interviews were recorded, saved in $\mathrm{mp} 3$ format, and transcribed to an MS Word document.

\section{Methods of data analysis}

The data were analyzed in a way that allowed for the capture of the essence of lived experience (Hendl, 2016). A classic analysis strategy was used, the acquired data were analyzed in the paper version. The data were processed according to the Steps of Analysis, as described by Kvale and Brinkmann (2009).

Meaning condensation was used, which, according to Kvale and Brinkmann (2009), entails condensing the meanings expressed by the interviewees into a shorter, more succinct formulation. It was an effort to capture the diversity of perspectives of the participants and synthesize data to maintain the richness of the communicated experience (Hendl, 2016).

The analysis process of coding, categorizing and defining themes was used according to Hendl (2016). The long statements of the interviewees were reformulated into several words with the same meaning and was used for creating the codes (Kvale and Brinkmann, 2009). It was then re-checked that all codes were well condensed. The data were analyzed in their entirety. Concerning the process of code generation - following the first suggested name, the codes were re-checked if they matched the meaning raised in the interview.

The authors of the study searched for similarities between the code contents and then suitable categories were created. Then categories were grouped into themes. It was also verified again that all of the associated codes cohered well. The tables with the created codes, categories and themes were shown to and discussed by two therapists, who themselves lead the RCs. Some categories and themes were finally clarified. During the data analysis, the process of going back and forth was used. In the text, quotes from participants (page/line) are used.

\section{Ethical considerations}

Consideration of ethical issues was imperative during the whole study (Kvale and Brinkmann, 2009). These included the selection and contacting of the participants, written informed consents, anonymity and confidentiality in work with data-transcripts, analysis, data holding and writing of the article.

The author was well aware of and paid special attention to ethical aspects of working with participants with ABI diagnosis - memory capacity, attention, tiredness, dysarthria (speech intelligibility), aphasia (search for words) etc. (Švestková et al., 2017).

\section{Results}

The collected data contain a rich description of the participants' experiences. These allow the reader to empathize with the subject and experience the described situation (Hendl, 2016).

A thorough analysis of the collected data yielded a total of twenty-one categories. These were then grouped into six themes (see Table 2).

Table 2. An overview of generated themes with their subcategories

\begin{tabular}{|c|c|}
\hline Themes & Categories \\
\hline 1. Doing more & $\begin{array}{l}\text { 1. Doing social activities } \\
\text { 2. Creative activities } \\
\text { 3. More movement }\end{array}$ \\
\hline 2. Escaping stereotypes & $\begin{array}{l}\text { 4. New place, new possibilities } \\
\text { 5. Change of regime } \\
\text { 6. Family/therapists differences }\end{array}$ \\
\hline 3. Discovering hidden potential & $\begin{array}{l}\text { 7. Trying new things } \\
\text { 8. Overcoming fear } \\
\text { 9. Discovering hidden reserves } \\
\text { 10. "I can do it" }\end{array}$ \\
\hline 4. Finding Independence & $\begin{array}{l}\text { 11. Consciousness of independence } \\
\text { 12. Estimating my abilities } \\
\text { 13. Taking responsibility for myself }\end{array}$ \\
\hline 5. Transferring to normal life & $\begin{array}{l}\text { 14. Transfer of skills to my daily life } \\
\text { 15. Motivation for future activities } \\
\text { 16. Returning to previous activities } \\
\text { 17. Memories to take home } \\
\text { 18. Increased confidence }\end{array}$ \\
\hline 6. Building relationships & $\begin{array}{l}\text { 19. Contact with people } \\
\text { 20. Comparing myself } \\
\text { 21. I can help means I am useful }\end{array}$ \\
\hline
\end{tabular}




\section{Theme 1. Doing more}

Throughout the interviews, the participants frequently mentioned various activities that were carried out.

Concerning social activities, most of the participants noted group-based activities. These varied from more general travelling-related experiences (e.g. going by train, trips to the city, visits to coffee bars or museums) to more social activities (playing games, barbecue, dance party). In connection to the raised topics, the interviewees often mentioned the importance of such social activities in their previous life.

Most of the participants referred to different creative activities (including Mandalas, Dyeing fabrics, or Creating gift bags) and their surprise and happiness over their newly discovered manual skills.

More movement arises as essential for the interviewees; all of them referred to movement-related activities such as walking or fine motor skills. Also, doing sports was mentioned by the majority. The noted activities included the following sports - Petanque, Croquet, Jumping on a trampoline, Recumbent bike, Hockey, Bowling, Golf, Swimming in a pond or pool, Warm-up exercise. Quote from Participant E (2nd page/1st line): "There are a lot of sports and walking, and it is beneficial that one is made to get used to the movement which I was previously used to doing. For a healthy person that is considered normal, but for us, it is not." The participants expressed how normal movement has become a more conscious activity for them.

\section{Theme 2. Escaping stereotypes}

Three categories emerged within this theme.

As for the new place, new possibilities, all of the interviewees talked about changes that included the change of location (what it means for them) and the accompanying alteration of habits and stereotypes.

Concerning the change of regime, some participants mentioned difficulties in getting used to a new regime, but this was overall perceived as a chance for a revival of "ordinary" life. In addition, a quote from Participant $C(1 / 29)$ demonstrates that filling the daily programme with various activities was considered an important aspect: "They always had, even if it was bad weather, some activity prepared for us that occupied our attention. And that those activities were not always the same... it's always the best." Similarly, other participants expressed that they felt occupied by the activities, and at the same time were satisfied to have exceeded their usual daily activity.

Participants expressed the different approach of the therapists compared to their family members. Participant A (3/7): “... some therapists let someone who should learn to use a wheelchair smash into a wall, because they know that nothing will happen to him, while at home they would catch me and help me and that's not always the best." In contrast to the attendee's relatives, the therapists are encouraging participant to perform activities on his own.

\section{Theme 3. Discovering hidden potential}

This theme was created from four categories.

Trying new things. Most of the participants described how it was important for them to try novel, seemingly ordinary things. Participant D (6/29) talked about routine but important activity: "I ran upstairs a few times on my own without even thinking about it, and without getting someone to guard me, which I had never dared to do before."

They emphasized that they had not previously realized that they could manage those activities on their own. Initially, they observed anxiety, but then experienced pride upon over- coming the fear. This phenomenon frequently occurred during sports activities or creative activities.

In some cases, the attendees were surprised to discover their "hidden reserves" by trying novel or unfamiliar activities, as Participant C (2/12) demonstrates: "I'm not very manually skilled, but I found my intrinsic hidden reserves and suddenly I realized that basically, I can do it. I did things which I have never done before, and it went well."

Frequently, the camp participants mentioned the wonderful feeling of "I can do it" as they surpassed themselves; for example, Participant C (5/6) mentioned: "Finally, it was no stress at all. ... when I was standing or lying on the recumbent bike, so I surpassed myself ... I liked that... to do things that we would otherwise not have had the courage for." In that matter, participants also expressed that they have gained more confidence and motivation to do similar tasks after returning home.

\section{Theme 4. Finding Independence}

The fourth theme encompassed three categories.

Independence and the knowledge of "being independent" was one of the earliest and at the same time one of the most frequent topics to appear during the interviews. Participant A (3/25): "Even without the constant help of the family, I am somehow able to do things independently." And in that sense Participant E (1/30) mentions: "For me, to be independent has the same meaning as to be an adult."

Estimation of individual abilities was of significance (what I can do on my own and when to ask for help). Participant A (2/3): "Because I want to trouble others as little as possible, I try to do far more things on my own." Participants note that the attempt for independence was frequently motivated by the effort not to bother the assistants with requests for help.

As an intrinsic part of the independent behaviour, the interviewees mentioned taking over responsibility; Participant F (2/1): "It just makes sense in my life that I will not be dependent on someone till the end of my days." Interestingly, making decisions concerning the smallest things, such as a dress choice, were sometimes perceived as essential life task. All interviewees considered the status of being independent and taking care of themselves as one of the most important aspects of the camp.

\section{Theme 5. Transferring to normal life}

In Theme 5, five categories arose.

Most participants described a particular activity that they transferred to their daily life following their return home. They mentioned different ADL activities, or the implementation of an ability gained from a creative activity to ADL, e.g.: "In the pub, I did not drink with a straw, but in a normal way... now at home I also drink from a glass." - Participant B (3/9).

The camp attendees noted their motivation to continue with the novel activities after returning home. Moreover, some of them mentioned the necessity to teach a family member the new activity encountered at the RC (e.g. a creative activities or a game).

Four participants admitted to having succeeded in re-introducing a previous activity into their normal life. In particular, those were the activities previously important and re-encountered at the camp (e.g. dancing and fishing).

The participants considered it equally important to bring home memories and have an opportunity to talk about them. This is expressed in a quote by Participant C (6/24): “... well, it is as if you return from a vacation and have a lot of experience, so even if it was only for a week, it is a lot of different experiences." 
Three interviewees noted that the participation in the camp increased their confidence, and whilst the other ones did not state this clearly, it was detectable from their speech. This was expressed by Participant F (1/29): "I do not know how to say it ... it has had a psychological significance; it gives me a confidence that I can take care of myself." And also by Participant C (6/11): "There are several activities, that we would hardly do... it raised our self-confidence... I think of all of us... because everyone left excited." Following their return, the participants considered themselves more confident and prepared to change the patterns of their daily lives.

\section{Theme 6. Building relationships}

The three following categories gave rise to Theme 6 .

All the participants stressed the importance of contact with other people (i.e. meeting new friends, chatting, being among other people, and both positive and negative aspects of social contact). While some participants were aware of the fact that the newly established relationships usually do not survive after the camp, others mentioned that in some cases the contacts persisted for years (via emails, visits, or calls).

The interviewees considered praise from other attendees very important. Frequently, they compare themselves with their peers and observe and rank their performance within the group. The mastering of a similar task by a person with a diagnosis comparable to their own is considered inspiring.

Four participants appreciated various aspects of helping others and they expressed that they felt useful. Participant F (8/5) said: "Well, I like that we patients know each other so well... I do not need to ask for help, but they come straight to me and ask: do you need me to push your wheelchair? So I like that relationship between us, that we help each other." Participant D (1/35) expressed a similar idea: "So it was interesting for me to see how some are doing better, some worse than me, and everyone was a bit disabled so we helped each other..."

\section{Discussion}

The purpose of this study was to uncover and describe the personal experience of the $\mathrm{RC}$ participants. The findings were generated predominantly from six in-depth interviews with the $\mathrm{RC}$ attendees. Moreover, the personal experience of the author indicates that these conclusions might also be strongly relevant to further participants.

\section{Theme "Doing more"}

Townsend and Polatajko (2013) noted that "Occupational behaviour is that aspect or class of human action that encompasses mental and physical doing". From the interviews, it became evident that at the RCs the attendees are encouraged to perform more activities compared to their ordinary life. This is coherent with literature that describes typical camp activities to include swimming, arts and crafts, cooking, dancing, hiking in nature, fishing etc. (Blinde and McClung, 1997; O'Mahar et al., 2010). Besides planned activities, it is also important to schedule hang-out time for spending leisure time together (Goodwin and Staples, 2005). An important part of activities is represented by sports. Martin (2010) describes the psychosocial benefits of sporting activities, which include engagement, self-esteem, development of friendship, broadening of social contact, health benefits and greater independence. Disabled individuals can profit from various aspects that the engagement in sport brings about, such as increased self-esteem, enhanced mood or improved satisfaction with life (Hanson et al., 2001).

Furthermore, the findings clearly show that the participants' relation to movement has altered and become more conscious. Based on the interviews, one might speculate that when learnt in such a way, a particular activity is more easily remembered and readily transferable to normal life.

\section{Theme "Escaping stereotypes"}

$\mathrm{RC}$ is often the first and only place where the clients are not accompanied by their family. Alteration of participants common environment and stereotypes seems to be crucial. Dohnálek (2012) mentions that changing the environment plays an important role in helping clients with $\mathrm{ABI}$ diagnosis.

According to Kiernan et al. (2004), the camps offer an opportunity to spend time in supportive surroundings and provide a "time out". In relation to this, it is important to say that the camp participants appreciate the feeling of safety throughout the RC. The overall findings of this theme clearly state that participants consider change to be very important. Such modifications provide them with an opportunity to escape the daily routine and to reflect on theirs and their family's stereotypes. They also mention that after returning home, this awareness was implemented into their ordinary life. This is also supported by other authors, such as O'Mahar et al. (2010) and Goodwin and Staples (2005), who state that spending time away from families facilitates greater independence. In that sense, the adjacent or more distant neighbourhood of the camp could be of a significant advantage - e.g. a coffee bar, sightseeing, cultural activities (Goodwin and Staples, 2005).

\section{Theme "Discovering hidden potential"}

In the course of the camp, participants are stimulated to overcome their fears, thereby discovering their hidden potentials. Dohnálek (2012) describes how the attendance of an RC has the potential to provide people with ABI with new experience and to help them to discover that they are able to handle more than they would imagine. In relation to this, Kiernan et al. (2004) mention that "feared activity can become a source of enjoyment rather than distress". Briery and Rabian (1999) demonstrated that the self-reported anxiety decreased over the duration of the camp. Overall, overcoming apprehension and trying new things seems essential (Goodwin and Staples, 2005). In that sense, the American Camp Association (2005) measured a growing willingness to try new things after camp attendance. The findings of this study indicate that overcoming fear represents an important process for the participants. By trying new activities, they discovered their hidden reserves, and subsequently felt more satisfied to have conquered a difficult task.

\section{Theme "Finding independence"}

During self-care, the RC participants often find new ways to be independent and are motivated to implement the newly gained skills into their daily lives after returning home. According to Kiernan et al. (2004), the RCs facilitate children to gain control over their actions. Goodwin and Staples (2005) discovered that campers felt more independent during and after the camp. Blinde and McClung (1997) highlighted the independence gained as one of the most important impacts of the camp. Moreover, an increase in leadership (being responsible for myself) and acquired independence was measured (by the American Camp Association, 2005) in children as late as six months after the camp had finished. All of these data indi- 
cate that the effects of the camp exceed the period spent there many times over.

This study comes to similar conclusions. The interviewees considered the status of being independent and taking care of themselves as one of the most important aspects of the camp. At the camp they enjoy more opportunities to do things on their own without any assistance from their family or carers.

\section{Theme "Transferring to normal life"}

The importance of returning to normal life and the accompanying strengthening of the physical and mental health is described by Goodwin and Staples (2005). They show a close connection between doing things independently and being more confident. These authors also described how the camp stimulated some attendees to re-consider their future and interestingly, even raised the prospect of moving away from home. Blinde and McClung (1997) stated that the participants also expressed elevated confidence and willingness to continue with the activity in the future. A statistically significant increase in self-esteem in children was reported by the American Camp Association (2005). Lastly, some authors, e.g. Dohnálek (2012), consider the rise in self-confidence to be one of the principal aims of the RC. All of this is coherent with the findings of this study, which implies the importance of transferring the gained experience to ordinary life. Following their return home, the participants consider themselves more confident and prepared to change the patterns of their daily lives.

\section{Theme "Building relationships"}

Social contact with others is a very important need of all human beings. Personal experience of other handicapped people can show the participants new possibilities, a new vision. Participants realize the importance of mutual contact with other individuals and, in addition, the establishment of new relationships. O'Mahar et al. (2010) state that an important aspect of the $\mathrm{RC}$ is that the attendees' experience a society of approximately equally affected people. Participants realize they are not unique with their problems, concerns and fears. At an RC, they can mutually exchange their experience of how to cope with their medical, psychological, social or family problems, letting the environment of the camp assist them to find solutions and their own way. Kiernan et al. (2004) mentions how an RC gives attendees a chance to talk with each other and to share the experience. Some studies note and at the same time highlight the possibility of repeated attendance of the camp. Briery and Rabian (1999) emphasize that contact with new and experienced campers could be of particular benefit. A certain continuity in camping (repeated participation of participants in the camp over consecutive years) is also recommended by O'Mahar et al. (2010). In addition, Goodwin and Staples (2005) describe the development of a strong feeling of community and belonging among the participants. Social interactions, meeting new people and making friends is also considered important in further studies by Blinde and McClung (1997) and by the American Camp Association (2005).

The camp attendees mentioned the way they compared their level of abilities with their peers. Moreover, they learned from the ways others coped with a particular situation. A high level of empathy was observed during the interviews; the participants considered helping each other and the accompanying feeling of being useful an important skill. The results of this study indicate that the majority of the attendees savour actively contributing to the camp.

\section{Methodological limitation}

This study is based on six in-depth interviews. The conclusions were only drawn from a limited number of attendees and likely do not reflect the full range of experience of further RC participants.

The published literature dealing with RCs is rather limited and old; up to date literature is missing. The majority of accessible articles concern camps for chronically ill children. Only a small number of studies originate from European countries, with a preponderance of US-origin research.

\section{Trustworthiness}

In this study, several methods were used to assure trustworthiness: peer discussions between the author and the RC leaders (with different professions and experiences); reflective thinking about any possible bias, description of data without excluding any information related to the aim of the study (Shenton, 2004), and of findings in terms of credibility, transferability, dependability, and confirmability.

\section{Therapist/Researcher}

The main author of this study is well aware of her dual role of researcher and therapist represented by a single person and about all possible biases. According to Guillemin and Gillam (2004), it is necessary to remain self-reflective throughout the study. A combined researcher/therapist approach does not only bring about disadvantages, but may also be beneficial at the same time (Damianakis and Woodford, 2012). Due to the established relationship of the author with the participants, the interviewees may in turn display more openness in their answers.

\section{Conclusions}

This study makes an important contribution to the understanding of several aspects of how participants with ABI diagnosis experience their activities at the $\mathrm{RC}$.

The unique findings of this study highlight the significant benefit the camps offer to their participants. Attendees perform more activities and change the patterns of their daily lives in comparison to their state before the RC. They are also stimulated to overcome their fears, thereby discovering their hidden potentials. By taking care of themselves, the attendees often find new ways to be independent and are motivated to implement the newly gained skills into their lives after returning home. They also realize the importance of mutual contact with others and establish new relationships.

The camps seem to provoke enhanced opportunities for attendees to experience all aspects of life within their changed capacities. Following discharge from the hospital, the camp's activities provided opportunities for easier re-integration into society. The natural, constantly stimulating rehabilitation environment of the $\mathrm{RC}$ could be considered the right setting for the stimulation of the independence skills of ABI clients. The participants are made to perform various activities that simulate their daily routine under the supervision of therapists. To sum up, RCs should be considered an important stage of the rehabilitation process for people with $\mathrm{ABI}$ diagnosis.

\section{Conflicts of interests}

The authors have no conflict of interests to declare.

\section{Acknowledgements}

This study was supported by the Specific University Research (SVV) Programme No. 260500. 


\section{Zkušenosti účastníků rekondičních pobytů}

\section{Souhrn}

Úvod: Umožnit osobám po získaném poškození mozku (ABI) návrat do samostatného života je výzvou pro rehabilitaci. Ve spolupráci s Klinikou rehabilitačního lékařství 1. LF UK a VFN v Praze organizuje obecně prospěšná společnost Rehalb týdenní rekondiční pobyty $(\mathrm{RC})$. Jde o cílené odvezení osob s postižením z nemocničního prostředí do náročnějších podmínek v přírodě, aby se podpořila a povzbudila jejich samostatnost.

Cíl: Cílem této studie bylo odhalit a popsat osobní zkušenosti účastníků rekondičního pobytu.

Metody: Byl použit fenomenologický př́istup. Data byla získána z 6 hloubkových rozhovorů.

Výsledky: RC přináší více příležitostí pro pozměněný potenciál (kapacitu) účastníků. Aktivity prováděné během pobytu jim poskytují př́ležitosti pro snadnější opětovné začlenění do společnosti. Významný pokrok byl pozorován v souvisejících aspektech. Bylo identifikováno šest témat, která zahrnovala několik kategorií: „Dělat více“; „Uniknutí stereotypům“; „Objevování skrytého potenciálu“; „Hledání nezávislosti“; „Přenos do normálního života“ a „Budování vztahü“.

Závěr: Přirozené, podnětné rehabilitační prostředí pobytů je považováno za velmi vhodné pro interdisciplinární stimulaci a trénink nezávislosti klientů s ABI. V tomto ohledu lze RC považovat za důležitou součást rehabilitačního procesu u osob s diagnózou ABI.

Klíčová slova: dospělý; ergoterapie; interdisciplinární tým; rekondiční pobyt; získané poškození mozku

\section{References}

1. American Camp Association (2005). Directions: Youth Development Outcomes of the Camp Experience, A study conducted by Phillibier Research Associates and the American Camp Association. [online] [cit. 2020-10-30]. Available from: http://www.acacamps.org/research/enhance/directions

2. Blinde EM, McClung LR (1997). Enhancing the physical and social self through recreational activity: Accounts of individual with physical disabilities. Adapt Phys Activ Q 14(4): 327-344.

3. Briery BG, Rabian B (1999). Psychosocial changes associated with participation in a pediatric summer camp. J Pediatr Psychol 24(2): 183-190. DOI: 10.1093/jpepsy/24.2.183.

4. Damianakis T, Woodford MR (2012). Qualitative Research With Small Connected Communities Generating New Knowledge While Upholding Research Ethics. Qual Health Res 22(5): 708-718. DOI: 10.1177/1049732311431444.

5. DePoy E, Gitlin LN (2019). Introduction to research: Understanding and applying multiple strategies. 6 th ed. St. Louis: Elsevier Mosby.

6. Dohnálek J (2012). S čím se chlubíme? [online] [2020-10-30]. Available from: http://www.ictus.cz/cim_se_chubime

7. Goodwin DL, Staples K (2005). The meaning of summer camp experiences to youths with disabilities. Adapt Phys Activ Q 22(2): 160-178. DOI: 10.1123/apaq.22.2.160.

8. Guillemin M, Gillam L (2004). Ethics, Reflexivity, and "Ethically Important Moments" in Research. Qual Inq 10(2): 261-280. DOI: $10.1177 / 1077800403262360$.

9. Hanson CS, Nabavi D, Yuen HK (2001). The effect of sports on level of community integration as reported by persons with spinal cord injury. Am J Occup Ther 55(3): 332-338. DOI: 10.5014/ajot.55.3.332.

10. Hendl J (2016). Kvalitativní výzkum. Základní teorie, metody a aplikace. 4th ed. Praha: Portál.

11. Kejklíčková I (2011). Logopedie v ošetřovatelské praxi. Praha: Grada, 128 p.

12. Kielhofner G (2006). Research in Occupational Therapy: Methods of Inquiry for Enhancing Practice. Philadelphia, PA: F. A. Davis Company.
13. Kiernan G, Gormley M, MacLachlan M (2004). Outcomes associated with participation in a therapeutic recreation camping programme for children from 15 European countries: Data from the 'Barretstown Studies'. Soc Sci Med 59(5): 903-913. DOI: 10.1016/j.socscimed.2003.12.010.

14. Kvale S, Brinkmann S (2009). InterViews: Learning the Craft of Qualitative Research Interviewing. 2nd ed. Thousand Oaks, CA: Sage Publication, Inc.

15. Maršálek P, Švestková O, Janečková M, Žílová T (2011). Doporučení k organizaci systému zdravotně-sociální péče o pacienty po získaném poškození mozku. Praha: Cerebrum.

16. Martin JJ (2010). The Psychosocial Dynamics of Youth Disability Sport. Sport Sci Rev XIX(5-6). DOI: 10.2478/v10237011-0032-9.

17. O’Mahar K, Holmbeck GN, Jandasek B, Zukerman J (2010). A Camp-based Intervention Targeting Independence Among Individuals with Spina Bifida. J Pediatr Psychol 35(8): 848-856. DOI: 10.1093/jpepsy/jsp125.

18. Rodová Z, Nováková O (2011). Rekondiční pobyty - most mezi teorií a praxí, Sborník př́spěvků z 23. celostátní odborné konference České asociace ergoterapeutů. Praha: Česká asociace ergoterapeutů.

19. Shenton AK (2004). Strategies for ensuring trustworthiness in qualitative research projects. Educ Inf 22(2): 63-75. DOI: 10.3233/EFI-2004-22201.

20. Švestková O, Angerová Y, Druga R, Pfeiffer J, Votava J (2017). Rehabilitace motoriky člověka. Praha: Grada, 320 p.

21. Townsend EA, Polatajko HJ (2013). Enabling Occupation II: Advancing an Occupational Therapy Vision for Health, Wellbeing \& Justice through Occupation. Canadian Association of Occupational Therapists. 2nd ed. Ottawa, Ontario: CAOT Publications ACE.

22. Vacková J (Ed.), et al. (2020). Sociální práce v systému koordinované rehabilitace. Praha: Grada, 208 p.

23. Wilcock AA, Hocking C (2015). An Occupational Perspective of Health. 3rd ed. Thorofare, NJ: Slack Incorporated.

24. WHO (2017). Rehabilitation in health systems. Geneva: World Health Organization. [online] [cit. 2021-05-01]. Available from: https://apps.who.int/iris/rest/bitstreams/1175964/retrieve 